\title{
Climate science in support of sustainable agriculture and food security
}

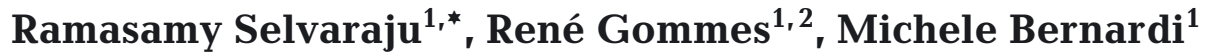 \\ ${ }^{1}$ Climate, Energy and Tenure Division (NRC), Food and Agriculture Organization of the United Nations, Rome 00153, Italy \\ ${ }^{2}$ Present address: European Commission Joint Research Centre, Ispra 21027, Italy
}

\begin{abstract}
Agriculture is deeply interconnected with weather and climate, the main drivers of agriculture production, but also the dominant factors in the overall variability of food production. Agriculture constitutes the principal livelihood of $70 \%$ of the world's poor; many of them are hungry and living in vulnerable, climate-sensitive areas. Since the undernourished population reached 1 billion persons in 2009, raising food production by some $70 \%$ to meet the needs of a projected world population of 9.1 billion people in 2050 may be one of the greatest challenges of the century. In addition, changes in climatic conditions are already having impacts on agriculture and the use of natural resources for food production. Climate science has much to offer in addressing these challenges, especially with respect to the characterisation of agroclimatic resources and development of climateresponsive food and agriculture policies, programmes and practices. However, as food systems expand into marginal and vulnerable areas, the need for a renewed, holistic focus is becoming evident, taking into account ecological, economic and social perspectives. Climate and agriculture services must therefore consider climate as a resource, understand current and future vulnerabilities and risks, and develop synergies that embrace innovation in climate science in order to facilitate sustainable agriculture and food security. The emerging ability of climate science to provide timely and accurate climate information, together with innovative tools and methods for analysis, presents opportunities for managing current climate risks and for initiating strategic climate-resilient adaptation in agriculture. However, to make effective use of these advancements, action-oriented climate advice should integrate information on different time scales (intra-seasonal, seasonal and long-term) for risk/ opportunity management and strategies for optimal and sustainable use of land, water and genetic resources. Strong partnerships and collaboration among international institutions, national hydrometeorological services, agricultural extension agencies, national research institutions, communitybased organisations and social networks are a prerequisite for the advancement of action-oriented advice. All of these efforts present key challenges, but offer immense opportunities, for both climate science and agriculture services, with respect to supporting sustainable agriculture and food security.
\end{abstract}

KEY WORDS: Climate science $\cdot$ Sustainable agriculture $\cdot$ Food security $\cdot$ Climate risk management Institutional partnerships

\section{INTRODUCTION}

Climate, as a natural resource, is probably the most important single factor in agriculture and food production. Agriculture remains highly sensitive to climate variations, which are the dominant source of the overall inter-annual variability in production in many regions and a continuing source of disruption to ecosystem services (Howden et al. 2007). Rural people, who depend on agriculture for sustenance and livelihood, are often vulnerable to the direct impacts of adverse weather, climate variations and change (Molnar 2010).

Many of the world's small-scale farmers, who work on marginal land in the tropics, have always been affected by climate variation. Increasing weather and climate variations affect the suitability of agricultural land for different types of crops and pastures. They have an impact on the productivity of forests, the inci- 
dence of pests and diseases, biodiversity, livestock, fisheries and the environmental health of food system resources. Maintaining and/or enhancing sustainability (see Section 3 for the definition of 'sustainability') of food system resources, economic profitability, and social and economic equity among rural poor are becoming more and more difficult under changing climatic and socio-economic conditions.

The world's population is expected to reach 9.1 billion by 2050; feeding this population would require raising overall food production by some $70 \%$ in 2050 compared to 2005/2007 levels (FAO 2009a). Sivakumar (2010) indicated that the economically active population in the more developed regions grew from 519 million in 1980 to 628 million in 2009, and the corresponding increase in less developed countries was much higher, from 1.38 billion in 1980 to 2.59 billion in 2009 . Sub-Saharan Africa, Asia and Latin America, with high rates of population growth and natural resource degradation, are likely to continue to have a high rate of poverty and food insecurity. Rapidly raising population growth and diminishing arable land, particularly in less developed countries, has increased the stress on natural resources (Sivakumar et al. 2000) and threatens efforts to maintain sustainability.

Climate change adds complexity to the dual challenge of meeting food demand while also maintaining the sustainability of agriculture. This underlines the importance of 'climate-smart' agricultural policies, programmes and practices for future food security (FAO 2010c). Climate science has a major role to play in this, and in the designing and implemention of appropriate sustainable agricultural practices, irrespective of geographical regions and food systems.
2000, and will continue to increase in the future. Climate models project increased precipitation at high latitudes and in parts of the tropics, and decreased precipitation, in some sub-tropical and lower mid-latitude regions (Bates et al. 2008). The projected changes in climate patterns will have important implications for water availability, especially through mean run-off changes (Milly et al. 2005), glacier melt during the summer season, ground-water recharge and floods (Kleinen \& Petschel-Held 2007); changes in hydrology will also have effects on geomorphic processes including erosion, slope stability, channel changes, and sediment transport (Dennis et al. 2003).

During the past $50 \mathrm{yr}$, global average cereal production has increased nearly 3-fold, a trend achieved largely by high-yielding varieties, intensive inputs and irrigation, but now threatened by stagnant or even declining per capita grain production (Fig. 1). According to the FAO (2007), agriculture accounts for about $70 \%$ of all water use worldwide and up to $95 \%$ in many developing countries, and irrigation covers $>277$ million ha of land. Given the dominant role of irrigated agriculture in global water use, management practices that increase water productivity can greatly enhance the sustainability of agriculture.

Changes in climate extremes are already having impacts on social, economic and natural systems, and future changes associated with continued warming will present additional challenges (Karl et al. 2008). The intensity of tropical cyclones (Knutson et al. 2010) and frequency of heavy precipitation events are very likely to increase over many areas during the 21st century, with consequences for the risk of floods. At the same time, the proportions of arid lands are projected to increase, in addition to a tendency for drying during

\section{AGRICULTURE IN A CHANGING CONTEXT}

The number of chronically undernourished people in the world has risen from 842 million in the 1990s to 1.02 billion in 2009 (FAO 2009b). Of the rural population, a significant proportion of those that depend on agriculture for a livelihood are hungry and often vulnerable to the direct effects of adverse climate events. However, the ability of agriculture to achieve global food security could be severely affected by a number of risks and challenges in addition to the growing population and demand for food.

According to the UNDP (2006), water use has increased rapidly over the past century, by >7-fold between 1900 and

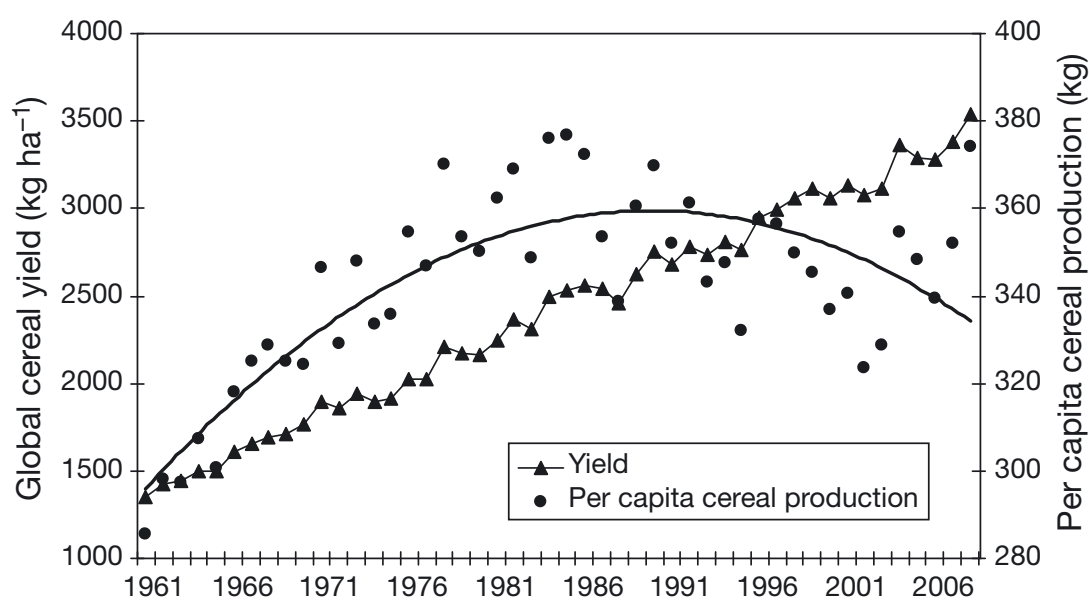

Fig. 1. Average global cereal yields and per capita cereal production (kg) for 1961-2008 (annual global per capita cereal production, calculated as total global production for a given year divided by total global population for that year) (FAO 2010a) 
summer, especially in the sub-tropics, low and midlatitudes (Bates et al. 2008). The vulnerability of these sensitive regions to impacts of hydro-meteorological disasters, in terms of loss of assets and economic value, has increased dramatically over the past few decades despite ongoing efforts (Mills 2005) in several sectors including agriculture.

Agricultural biodiversity (i.e. genetic, species and ecosystem diversity within the agricultural landscape) plays several key functions in sustainable food and livelihood security, but is threatened by climate change and increasing climate variability. The IPCC Fourth Assessment Report (IPCC 2007a) projected an increasing risk of species extinction with higher confidence as warming proceeds. The report elaborated that approximately $20-30 \%$ of plant and animal species assessed so far are likely to be at increased risk of extinction if increases in global average temperature exceed $1.5-2.5^{\circ} \mathrm{C}$ over $1980-1999$ levels. If management of agricultural biodiversity fails to consider climate-related impacts, some key functions of the agroecosystem may be lost, such as maintenance of nutrient and water cycles and levels, pest and disease regulation, pollination and land-erosion control.

Changes in incidence, distribution and intensity of pests and diseases due to climate change are likely to cause additional crises in local agricultural production. The range of crop weeds, insects and diseases are projected to expand to higher latitudes (Rosenzweig et al. 2001). In particular, $\mathrm{CO}_{2}$-temperature and $\mathrm{CO}_{2}-$ precipitation interactions are recognised as the key factors in determining the intensity of damage from pests (Easterling et al. 2007). Climate change is likely to affect vector-borne diseases and may also result in new transmission pathways and different host species (Garrett et al. 2006).

Food-system-dependent communities in coastal, mountain and arid regions will be particularly vulnerable to climate impacts. Coastal zones constitute extensive areas of the most vulnerable ecosystems, and are strongly exposed to natural risks such as floods, storms, erosion and salt-water intrusion. Fisheries-dependent communities are particularly vulnerable to rising sea levels, changes in ocean salinity, cyclones, and a decrease in fish stocks and availability due to increasing water temperature (Hall-Spencer et al. 2008). Most of the large global marine fisheries are affected by climate variability associated with the El Niño-Southern Oscillation (ENSO) and Pacific Decadal Oscillation (Lehodey et al. 2003). The combined effects of predicted warming, the relative importance of fisheries to many national economies and diets, and the limited capacity to adapt to impacts of climate change are the major reasons for the vulnerability of coastal zones (Allison et al. 2009).
Mountain regions cover about one-fifth of the Earth's continental areas, and are often home to cultural minorities. Mountain regions are characterised by sensitive ecosystems, and sloping lands compound the destructive power of storms and heavy rains, producing avalanches, landslides and floods. Remoteness, marginalisation and the non-availability of advanced early warning systems for climate-related threats make them highly vulnerable. Increasing populations in mountain regions, heavy dependence on agriculture and livestock, unplanned settlements, excessive land degradation, and commercial forest logging have led to unsustainable management of natural resources (FAO 2009c).

Arid and semi-arid areas are vulnerable to climate impacts because of highly variable and scarce rainfall combined with over-exploitation and degradation of natural resources. Even a slight warming decreases yields in dry and tropical areas (IPCC 2007a) and will increase the risk of hunger. Arid and semi-arid areas are prone to frequent droughts, which can lead to an increased vulnerability of land to desertification or to the escalation of the desertification process.

\section{CLIMATE, FOOD SECURITY AND SUSTAINABLE AGRICULTURE}

Climate change and increasing climate variability will affect food security in all of its 4 dimensionsavailability, accessibility, utilisation and stability (FAO 2008b). More frequent and intense extreme weather events and increasing uncertainty in rainy season patterns are already having significant impacts on food production, food distribution infrastructure, livelihood assets, human health and food emergencies, in both rural and urban areas (FAO 2008a). Battisti \& Naylor (2009) concluded that projected changes in the frequency and severity of weather and climate events, including higher growing season temperature, have significant consequences for food production, farm income, and food security. Sustainable agriculture practices and adaptive adjustments to food system activities are needed all along the food chain to cope with the impacts of climate, its variability and projected change.

Sustainable agriculture is defined in different ways. Basically, sustainable agriculture integrates 3 major goals-environmental health, economic profitability, and social and economic equity. Sustainability rests on the principle that we must meet the needs of the present without compromising the ability of future generations to meet their own needs. Sivakumar et al. (2000) reviewed the definitions of sustainable agriculture and emphasised the need to set long-term goals that can be 
achieved by practices conditioned by relevant agroclimatic information. A systems perspective is essential to understand the role of agroclimatic information in achieving sustainability goals. The system is envisioned in its broadest sense, from the individual farm to the local ecosystem, and to communities affected by farming systems both locally and globally, along with their interactions with climate. A systems approach gives us the tools and methods to explore the interconnections between agriculture and climate. The definition of sustainable agriculture adopted by the FAO (FAO 1995) brings together all aspects of sustainability as follows: sustainable agricultural development is

the management and conservation of the natural resource base and the orientation of technological and institutional change in such a manner as to ensure the attainment and continued satisfaction of human needs for present and future generations. Such sustainable development (in the agriculture, forestry, and fisheries sectors) conserves land, water, plant and animal genetic resources, is environmentally non-degrading, technically appropriate, economically viable and socially acceptable.

The sustainability agenda seeks to integrate ecological, social and economic concerns into decision-making at both national and global policy levels (Dovers \& Handmer 1993). It is important to note that sustainable agriculture is the responsibility of all participants in the system, including farmers, service providers, policymakers, researchers, retailers and consumers. Each group has its own part to play, its own unique contribution to strengthen the sustainable agriculture community.

Climate science is already doing its own part by assisting in the systematic characterisation of agroclimatic resources, which represents one of the criteria for development of climate-responsive and resilient agricultural policies, programmes and practices. However, a renewed focus is needed, which (1) views climate as a resource contributing to the planning and management of the land, water, plant and animal genetic resource base; (2) incorporates weather and climate information in seasonal and intra-seasonal time scales to reduce the impacts of climate risks; and (3) uses medium to long-term climate change scenarios for enhancing resilient adaptation towards achieving sustainable agriculture (Fig. 2).

\section{CLIMATE AS A RESOURCE: MANAGING RESOURCES FOR SUSTAINABLE AGRICULTURE}

Climate is a basic resource for agriculture and drives almost every process from the ecosystem to plant level. Climate and weather interact with several physiological processes at the plant level, such as photosynthesis, remobilisation, maintenance, crop growth, crop development, assimilate partitioning, leaf area development, transpiration, evaporation, water and nutrient uptake and stress from a deficit/excess of water (Penning de Vries et al. 1989). Although the role of climate science in providing the required information for understanding these interactions at macro and micro levels has long been recognised, now a stage has come to revitalise and expand on this role by shifting the emphasis towards on-theground actions to achieve sustainable management of food system resources.

The provision of needs-based climate information to farmers can support management of the most important agriculture resources (land, water and genetic resources). Within the resource-management context, climate must be recognised as a resource, assessed in quantitative terms by climate and agriculture services, and communicated to, and properly managed by, farmers. Though farmers are already managing natural resources based on their experiences with local climate, traditional practices may be insufficient in a global change context. Under the changing context, an improved understanding of the climatic, biological and socio-economic components is essential.

Ensuring adequate food and water to all and achieving sustainable agriculture development for current and future generations will depend upon the sustain-

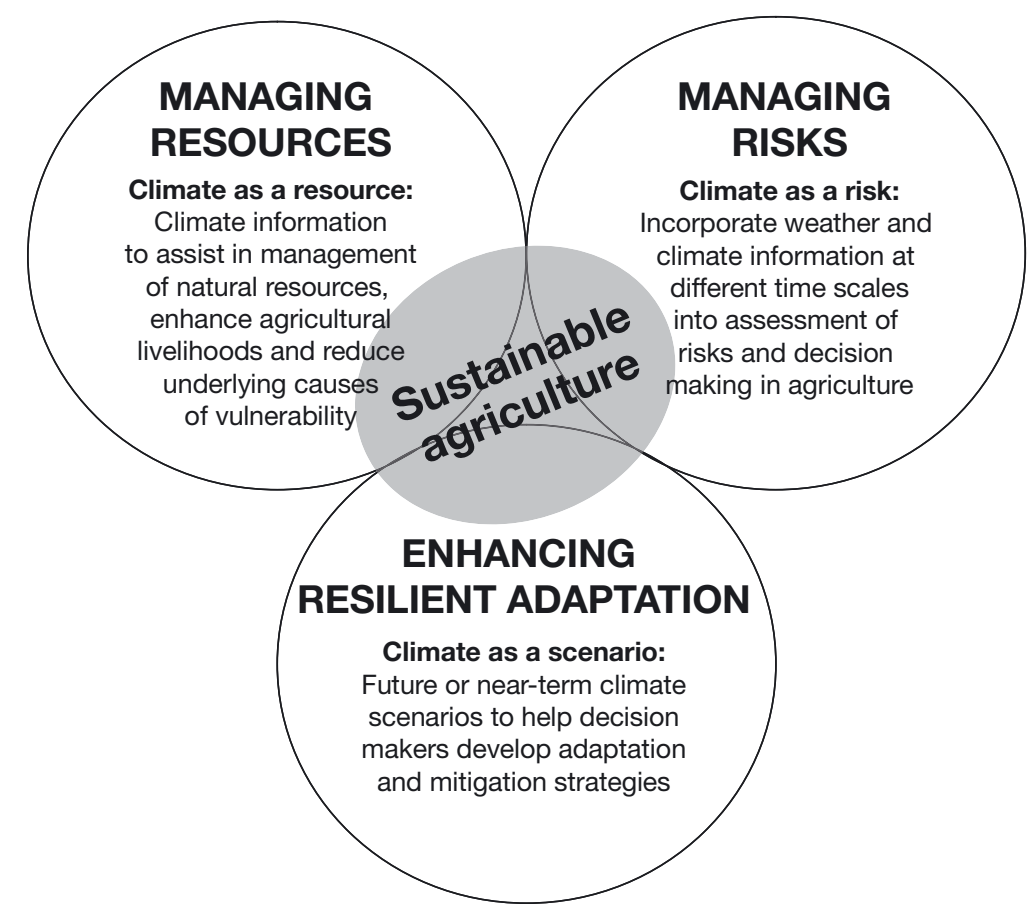

Fig. 2. Key areas of support from climate science towards sustainable agriculture 
able management of all natural resources, including climate. Sustainable natural resource management is one of the key entry points to reduce the impacts of climate (Tilman et al. 2002). The successful design of a natural resources management strategy in agriculture should consider vulnerabilities of agricultural systems to climate impacts, emerging areas of concern and climate hotspots. Glantz et al. (2009) propose that the management of natural resources through a climate window should be focussed on the identification of critical areas of concern even before a climate hotspot appears. Recent improvements in the provision of advance climate information allow the earlier identification of such areas of concern and aid in resource management.

Better understanding of the climate resource in a location provides opportunities to design various measures to reduce its impacts on natural resources (WRI 2009) during deviations from the long-term norm. The support of climate science is needed to understand these deviations and to make use of information on this resource for agro-ecological zoning, land-use planning and sustainable land management, for forest management considering climatic conditions and underground and surface water levels - which are related to rainfall expectations and infiltration rates - and for river basin management, including pre-release of water from dams in order to store expected excess water and avoid anticipated flooding and optimising water release in order to reduce water loss and enhance use efficiency.

Besides adjustment of management practices based on observed climatic conditions, practical actions could be implemented to overcome the damaging effects related to foreseen risks, considering sustainable management practices. The design of sustainable soil and water management practices requiring climate information include: soil and slope protection methods (i.e. terracing, growth of gross species for soil retension), reduction of run-off, enhancement of water storage potential in the upper soil layers by simple tillage practices and water conservation techniques such as basin tillage, tied ridging, broad-beds and furrows (Selvaraju et al. 1999), increase of infiltration to recharge groundwater and shifting of crop production share between upland and lowland fields based on water availability.

Efficient management of water resources requires exploring the linkages between climate, soil and plant interactions. Water harvesting, techniques to increase soil moisture content and reservoirs for irrigation contribute to reduce the uncertainty of water availability. Pretty et al. (2006) confirmed that these practices also provide a notable improvement in water productivity, especially for rain-fed agriculture. No-till systems are found to reduce water run-off, increase water infiltration and reduce soil erosion (Blanco-Canqui \& Lal
2008). Conservation tillage, combined with residue management, mulching and proper fertiliser use, can help to preserve soil moisture, ensure maximum water infiltration, minimise nutrient run-off and increase crop yields.

Bates et al. (2008) proposed incorporation of information about current climate variability into water management as a first step to assist in managing water resources effectively. The use of climate data and information for water resource management (Dutta et al. 2006), water demand and irrigation optimisation under drought conditions (Meza et al. 2008), and crop area decision strategies conditioned on climate information (Selvaraju et al. 2007) for better water resource management have demonstrated the role of climate science in water management and enhancing water productivity. Several of these pilot studies focussed on improving the reliability of seasonal-scale predictions and farm-level applicability. A potential for up-scaling these efforts exists, but they need strategic planning and implementation with sustained support from climate science.

Conservation and management of genetic resources is directly linked to climate. In general, the understanding of abiotic and biotic interactions in the context of climate variability and change assists in developing strategies for conserving plant and animal genetic resources. The simultaneous changes in temperature, precipitation, $\mathrm{CO}_{2}$ fertilisation, and pest and pathogen dynamics, mean that biodiversity conservation and breeding efforts need the support of climate science. Specifically, in order to promote agricultural adaptation in the face of climate change, crop-improvement researchers aiming to develop short-duration genotypes, tolerant to temperature and drought stress, resistant to pest and diseases, and to understand genotypeenvironment interactions, require knowledge about the future climate. As breeding investments typically run in 12 to $20 \mathrm{yr}$ cycles, assessing the potential impacts of climate change is needed to identify the appropriate breeding strategies.

In their analysis of the effect of climatic instability on agriculture and the possibilities of reducing inputs, Romay et al. (2010) identified yield stability across environments as a critical breeding goal, and noted that climate information is essential in the development of stable maize genotypes. Crop-breeding programmes aim to select plants with stable genotypes across environments, requiring the support of climate services (Hammer et al. 2010). Therefore, if yield under stress conditions is a breeding goal, several climatic variables, especially those related to high temperatures, should be considered. Similarly, climate information should be considered when selecting suitable locations for in situ conservation of genetic resources (FAO 2008c). 


\section{CLIMATE AS A RISK: MANAGING RISKS FOR SUSTAINABLE AGRICULTURE}

Recent advances in climate prediction, analysis and synthesis of climate knowledge have helped improve climate-risk management with the potential to enhance livelihood opportunities in agriculture. Monitoring and analysis of meteorological and climatic data provide advance information about soil moisture conditions and crop state, in quality and quantity, with the proactive potential of managing climate risk. Cropyield forecasting has long been used as a strategy to manage climate risks, but needs various kinds of data collected from different sources: meteorological data, agrometeorological, soil and remotely sensed, agricultural statistics (Gommes 1998). Based on meteorological and agronomic data, several value-added indices can be derived, which are relevant in monitoring soil and crop conditions and determining crop yield for climate risk prevention, preparedness and proactive food security management (Tadesse et al. 2008).

Weather and climate forecasts and early warning systems can be useful elements of the decision-making process in climate risk management (Challinor 2009). Hansen et al. (2006) emphasised that decision makers must prepare for a range of possibilities and must often employ risk management strategies that reduce the negative impacts of climate extremes and avoid the inefficient use of natural resources. Several case studies of the Climate and Agriculture (CLIMAG) programme have demonstrated the benefits of localised management practices conditioned by reliable climate information in reducing risks and improving agricultural production (Sivakumar \& Hansen 2007). Thus, to sustain all these efforts, agricultural policies, national extension services and national meteorological services must develop synergies to ensure that planning and management of crops, livestock, forests and fisheries benefit from climate-based advice. The role of climate science in the climate risk management of food and agriculture resources is more prominent than ever before, because food systems are expanding more and more into marginal, vulnerable and climate risk prone areas (FAO 2008a).

Intra-seasonal to inter-annual climate variability impacts the agricultural sector, and, therefore, many agricultural decisions can benefit from high-quality and reliable predictions. For example, in southern Asia, better prediction of the variability in summer monsoon rainfall on intra-seasonal time scales (Webster et al. 1998) is one of the fundamental requirements for agriculture development (Hoyos \& Webster 2007). Donald et al. (2004) emphasised that intra-seasonal forecasts are considered essential for making the appropriate decisions to modify strategies that reduce vulnerability for smallholder farmers and commercial producers.

There are several indices and methods used to explain the intra-seasonal climate variability relevant to agricultural applications in different regions. The passage of the Madden-Julian Oscillation has been described to explain patterns of suppression and/or enhancement of rainfall to be forecast beyond the synoptic scale (Bond \& Vecchi 2003). Propagation characteristics of the Monsoon Intra-Seasonal Oscillation provide indication of active and break monsoons in southern Asia (Hoyos \& Webster 2007). Tactical risk management can be improved through the application of intra-seasonal forecasting capabilities that will allow farmers to assess the timing and likelihood of rainfall events and temperature fluctuations at time scales of up to $6 \mathrm{wk}$.

On the other hand, strategic decisions in agriculture aiming to reduce risks require seasonal climate predictions. Seasonal climate predictions are very useful to agriculture ministries, non-governmental organisations and private companies for policy and the long-term planning process, in addition to strategic crop and livestock management decisions by farmers. The approaches to seasonal to inter-annual climate predictions and sources of predictability, including ENSO-related indices, offer a greater potential for risk reduction and opportunity management (Goddard et al. 2001). These developments have the potential to improve the economic return for both smallholder farmers and rural companies, such as grain traders, sugar mills and cotton gins (Hansen et al. 2006, Meinke et al. 2006).

However, applications of such forecasts require additional climate research on sources of predictability, important underlying climate processes and efforts for integration into the operational forecasting scheme to realise the potential benefits. The National Academy of Sciences (2010) concludes that operational intra-seasonal and inter-annual forecast centres can increase the value of forecasts to decision makers and researchers by modifying procedures for achieving and disseminating forecast information and enhancing collaborations with the external research community. Future improvements to observational capabilities, statistical and dynamical models, and data assimilation systems should permit these forecast systems to better represent the variables and processes that serve as sources of predictability.

Index-based insurance products for agriculture represent an attractive alternative for managing weather and climate risk (Skees 2008). The FAO (2005) estimated that the total annual agricultural and forestry insurance premiums worldwide in 2001 amounted to some US\$ 6.5 billion, representing just $0.4 \%$ of the estimated total farm gate value of agricultural production 
globally. As the current insurance mechanisms are not adequately covering the millions of smallholder farmers, climate science should play a major role in providing localized and needs-based climate information to farmers so as to encourage them to make use of insurance mechanisms. However, provision of localized and needs-based climate information to promote indexbased weather insurance requires strengthening of weather observation networks, monitoring of extreme climate events, standardisation of indices, data sharing, early warning systems and capacity building.

The insurance approach in Malawi, based on the FAO-evaluated index (Chavula \& Gommes 2006), uses a crop-specific water balance to derive value-added crop-weather variables that can be combined with other data. The methodology uses gridded information that compensates for individual missing stations. Nonetheless, the approach requires sufficient monitoring infrastructure and data points to ensure a realistic explanation of spatial variability. Therefore, index-based weather insurance systems require the support of climate science and national hydrometeorological services to ensure high-quality weather data, monitoring instruments and procedures to downscale weather information to produce real time crop yield indices covering a specific agro-ecological region.

Changing climate may change patterns of disease and pests through altered host distribution and phenology, may alter the plant-associated microflora and may trigger new plant diseases and pest outbreaks. Control and management of new diseases and pests require new indices on economic threshold levels and on their relationships with climate. Early detection of diseases and pest outbreaks based on weather and climate forecasts can assist proactive control measures and thus avoid higher management costs. By monitor- ing pest thresholds, climate information systems can assist in the development of integrated pest management technologies needed to counter new pests. Operational monitoring of pest and diseases, and weather-based early warning systems, have long been recognised as an essential part of integrated pest and disease management. Pest and disease forecast models, coupled with weather forecasts generated from climate simulations, can be a basis for pest and disease early warning systems (Shaw 2009).

Climate risk management at the farm scale refers to a combination of methodologies and approaches that helps to identify, analyse and prioritise the climaterelated vulnerabilities and risks and to optimise the adaptation and/or management practices in order to effectively respond to climate variability and change. The approach combines historical climate data with weather and climate forecast information for realtime analysis of impacts, and provides opportunities to generate viable options for farm decision-making in order to manage risks and enhance opportunities without compromising sustainability.

The localised climate-risk management system requires analysis of real time weather, crop information, weather and climate forecasts, costs of inputs and prices of farm produce to prepare needs-based and location specific farm advisories (Fig. 3). In addition to real-time information on weather and crops, historical climate data, location-specific socio-economic conditions and local coping strategies should be considered for analysis through the use of agrometeorological tools and methods to identify, quantify, monitor and inform about the vulnerabilities and risks and the ways to manage the risks and opportunities at the farm level. The localised climate risk management approach is accomplished by:

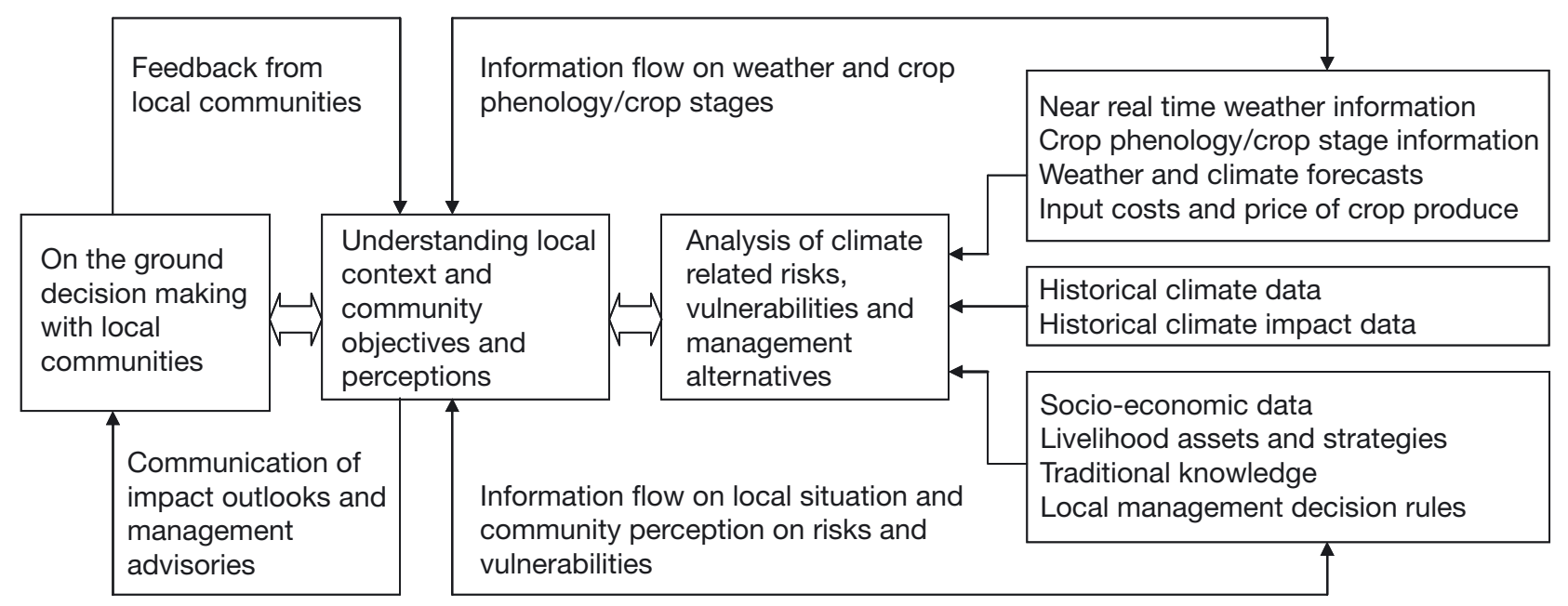

Fig. 3. Data and information flow in a localised climate risk management system 
- exploring and consolidating knowledge in local situations, including farmers' decision problems, physical and social vulnerabilities, risks and environmental conditions and available climate data and information products;

- analysing vulnerability and climate risks, and optimising management decision options using a range of methods and tools (e.g. crop models), including past, near-real time and forecast products;

- deciding on appropriate management options, conditioned by the local situation and its needs, and developing customised information products to vulnerable communities;

- facilitating local actions through the communication of climate information, relevant options and the monitoring and evaluation of the feedback process.

Four main elements in localised climate risk management systems are recognised: (1) climate, crop and socio-economic data collection (2) analysis/prediction, (3) the development of adaptive management practices and (4) the preparation of farmer agro-advisors. The approach aims to provide a full range of advice regarding crops to be planted, time and quantity of inputs that might be used, and management practices to be followed to prevent and/or to reduce risks, so that they will be ready to execute management decisions at short notice based on the anticipated weather and climate. The local advisories will detail the information on input availability with agricultural support services, input suppliers, local cooperatives and farmer service-based community organisations to advance practical decisionmaking, not only based on climate information, but also depending on the necessary input availability. With modern, low-cost information and communication technologies, information can now be systematically collected in real-time from local communities, analysed by the technical institutions working on climate and agricultural services, and optimal management practices can be communicated to farmers.

Climate information can be combined to livelihood analysis and market information systems, to improve early action planning to overcome disaster and foodstress situations. As large and widely dispersed populations depend on rain-fed agriculture and pastoralism, climate monitoring through modern technologies and forecasting are important inputs to food security analysis and humanitarian responses. Verdin et al. (2005) emphasised satellite rainfall estimates for climate monitoring as critical input in the production of drought index maps and crop water balance models. Similarly, remote sensing techniques (De Groeve \& Riva 2009), satellite rainfall estimates and ensemble forecasting schemes (Hopson \& Webster 2010) for operational flood forecasting offer significant opportunities for protection of agricultural livelihoods and against food- related emergencies. For example, the FAO's Rainfall Estimate Routine-an independent method to estimate the amount of rainfall (www.fao.org/nr/climpag/ data_2_en.asp), particularly for certain regions in Africa-provides opportunities to enhance the national capacities for climate risk management and emergency responses.

The climate risk management approach is considered a major tool in reducing the impacts of growing extreme climate events. Data of the FAO's global information and early warning system on food and agriculture indicate that sudden-onset disasters-especially floods - have increased from $14 \%$ of all natural disasters in the 1980 s to $20 \%$ in the 1990 s and $27 \%$ since 2000 (FAO 2008d). As sudden-onset emergencies with extensive and catastrophic severity leave much less time for planning and response than less severe slowonset events, these trends have important implications for the planning of risk reduction measures and the mobilisation of resources needed to prepare for and respond to emergencies in order to protect agriculturebased livelihood systems. As the response to climaterelated risks depends on hazard severity and frequency, climate information for assessment of climate risks on spatial and temporal scales plays a major role in the planning of appropriate responses. Fig. 4 illustrates climate-related risk scenarios and the indicative typology of responses in food and agriculture depending on hazard severity and frequency.

In the absence of safety nets and the appropriate financial support mechanisms, humanitarian aid is required to enable households to effectively cope with emergencies and manage their limited resources more efficiently (Haile 2005). Timely and effective humanitarian aid will provide households with opportunities to engage in productive and sustainable livelihood strategies. Investments in poverty-reduction efforts would have a stronger impact if complemented with response mechanisms that would ensure the protection of livelihoods during crisis periods related to extreme weather events. With improved understanding of climate variability, including ENSO effects, the implications of weather variables for the food security and vulnerability of rural communities have become more predictable and can be monitored more effectively.

A further application of climate and weather services is through information that aids decision making on food-grain and seed storage. The effects of rainfall, air moisture and temperature are critical for the correct storage of grain, while the effects of sun and wind are beneficial for the drying process. If the farmer can base his decisions on an accurate prediction for the following 5-7 $d$, he can reduce the risk of damage to his grain during the drying process. Information about the 


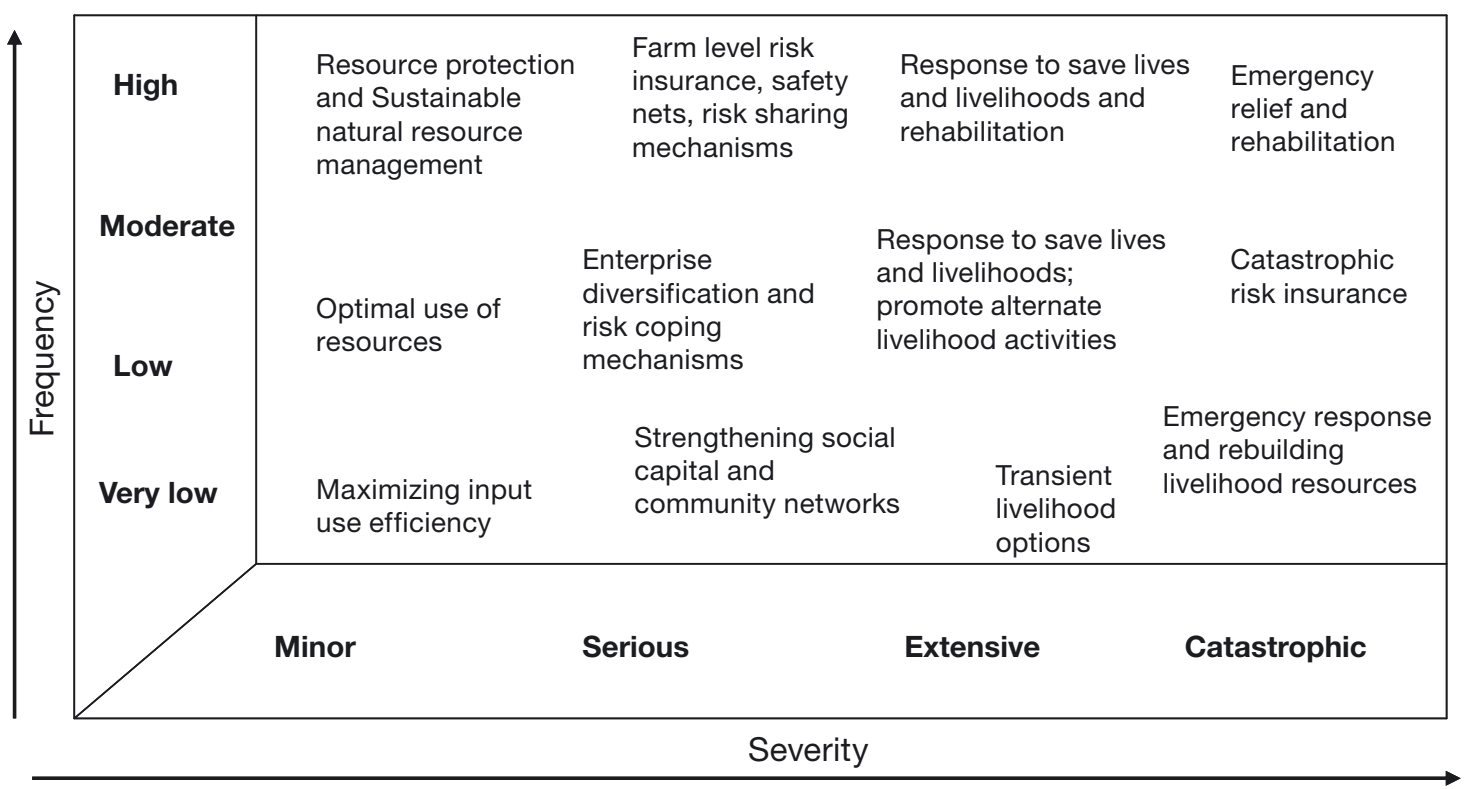

Fig. 4. Climate-related risk scenarios and indicative typology of responses in food and agriculture

weather becomes even more important with the introduction of short-season-variety crops, which are ready for storage before the normal dry season starts.

\section{CLIMATE AS A SCENARIO: ENHANCING RESILIENT ADAPTATION}

Resilient adaptation strategies are now a matter of urgency, especially for the most vulnerable poor countries. Resilient adaptation is a hybrid strategy, merging adaptation, mitigation and even prevention to produce an overall strategy (Glantz et al. 2009). Climate science provides the most important input-'climate scenarios' - to enable the development of resilient adaptation strategies. Climate scenarios help to evaluate uncertainty about human contributions to climate change, the response of the Earth's ecosystem to human activities, the impacts of a range of future climates, and the implications of different approaches to adaptation and mitigation (Moss et al. 2010).

Developing and implementing climate change adaptation and advice to policymakers and farmers should also focus on livelihoods and food security, and the following can all become an integral part of the livelihood adaptation process: increasing awareness of climate change at the grassroots level; provision of essential support-such as information, technology, alternate sources of income and employment, post-harvest facilities, credit facilities and insurance mechanisms; information on markets; and dissemination of early warning information at the local level.
Information about climate scenarios and possible shifts in seasonal rainfall pattern can be used in the planning of alternate strategies for grazing and livestock management. Thornton et al. (2009) reiterated the need for climate information to support livestockbased livelihoods and herders' decisions about moving to alternative grazing areas and deciding on stock numbers as forms of advance adaptation to climate change. Climate and weather services provide opportunities for the estimation of bush-fire risks based on scenarios of temperature, humidity and wind and, thus, assist in protecting the livelihood assets of indigenous populations and of forest-dependent communities.

Climate information is central to vulnerability and impact assessment, local planning, the prioritization of local coping and adaptation strategies, the implementation of adaptation practices, policy support and upscaling (Fig. 5). Vulnerability assessment encompasses evaluation of the impacts of variability and change in mean climate on agricultural systems, given knowledge on the biophysical and socioeconomic context and the available adaptation options to climate change. However, agricultural production systems have their own dynamics, and thus design of improved adaptation strategies is particularly important to reduce the location-specific impacts of climate change. Within this context, Moss et al. (2010) emphasised that the support of climate science in providing the next generation of scenarios for climate change and assessment is one of the highest priorities for delineating vulnerable zones and hot spots of risks, and, thus, it could serve as a basis for the design of localised adaptation strategies. 


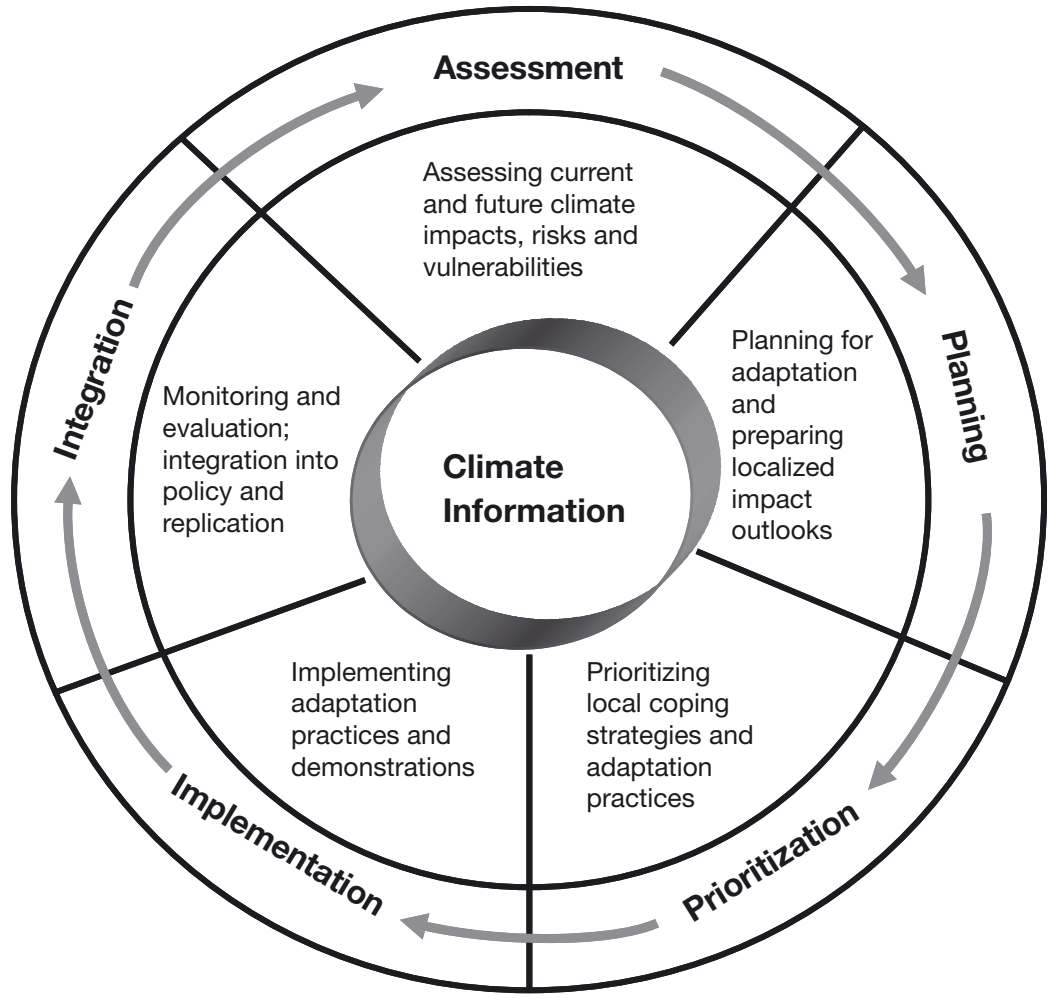

Fig. 5. Role of climate information in assessment of impacts, local vulnerabilities, planning for adaptation, prioritization of adaptation practices, local implementation and policy integration

Understanding location-specific vulnerabilities facilitates adaptation to climate variability and change, as well as adding to our information on the characteristics of system vulnerability and adaptation effectiveness, such as resilience and coping mechanisms. In addition to the primary role of climate knowledge in adaptation planning, it helps in planning climate-change mitigation strategies just as the prevailing weather and climatic conditions determine the effectiveness of mitigation efforts. According to the IPCC 4th Assessment Report (IPCC 2007b), sustainable agriculture practices can make a significant contribution, at a low cost, to increasing soil carbon sinks, to GHG emission reduction, and to the contribution of biomass feedstock for energy use. The actions, such as increasing soil carbon sequestration through improved crop and grazing land management (e.g. improved agronomic practices, conservation tillage and crop residue management), forestry and agroforestry initiatives (Palm et al. 2005), improving the efficiency of nutrient management and the restoration of organic soils (Lal \& Follett 2009), and the conservation of agricultural and degraded lands, are affected by air and soil temperature and soil-moisture regimes. In addition, advances in climate modelling and forecasting technologies have raised the prospect of sustainable livestock and pasture management (Luseno et al. 2003) in grassland ecosystems.

\section{TOWARDS SUSTAINABLE AGRICUL- TURE: DATA, TOOLS AND METHODS}

Building a database of climatological, meteorological, phenological, soil and agronomic information is required to plan sustainable agriculture systems and production practices. Doraiswamy et al. (2000) stressed the need for a proper meteorological and agrometeorological database as a major prerequisite for studying and managing the process of agriculture production. Climate science and national climate services are well placed to provide the basic, essential climate data (Table 1) to inform agricultural planning and managing processes for production and crop yield at the farm level.

In addition to common agrometeorological data for planning purposes, data on climate change scenarios are needed for impact assessments, planning of adaptation and mitigation practices (Moss et al. 2010). Agriculture is one of the sectors for which complex impact assessment tools and methods are available, and these usually require a larger set of detailed climate variables than what is normally provided by national meteorological services in many developing countries (Vega 2008). Close cooperation between agencies and organisations dealing with agriculture and climate services is needed to establish a climate and crop data sharing platform for impact assessment.

Crop growth models are useful to better quantify climate risk associated with crop production, as well as to develop crop and soil management practices that reduce the risk to acceptable levels. Muchow \& Bellamy (1991) discussed quantitative approaches for assessment of climate risks in crop production, which included crop modelling approaches for the estimation of climate risk and the optimisation of agronomic management practices and decision-making to reduce risk. Crop growth simulation models coupled with data from geographic information systems are often employed to analyse crop suitability, spatio-temporal yield variability and water productivity at river-basin and regional scales (Ines et al. 2002).

Several methodologies have already been developed that combine observed meteorological variables, historical agriculture yields and climate change scenarios to simulate future yields incorporating the $\mathrm{CO}_{2}$ fertilisation effect, technological trends and potential adaptation options (UNFCCC 2008). A generic framework of the impact assessment methodology is shown in Fig. 6. Process-based crop growth models are frequently used for climate change impact assessment, which provides options for decision-making; these 
Table 1. Climatological and meteorological data required for planning agricultural and production practices at the local level

\begin{tabular}{|ll|}
\hline Types of data & Intended use \\
\hline $\begin{array}{l}\text { Historical daily/weekly/monthly } \\
\text { data on precipitation, temperature } \\
\text { (max., min.) solar radiation, relative }\end{array}$ & $\begin{array}{l}\text { Matching food system enterprises (e.g. crop, livestock, fisheries, etc.) to climate } \\
\text { humidity, evaporation, etc. }\end{array}$ \\
$\begin{array}{ll}\text { Celection of crops, varieties and cropping systems } \\
\text { Evaluation of water supply and methods of irrigation }\end{array}$ \\
Water requirement and crop water use estimation and irrigation system planning \\
Date of onset and termination of rainfall and length of growing period \\
Rainfall intensity and prioritisation of suitable run-off control or drainage practices \\
Planning and designing water harvesting structures \\
Crop-specific water balance and identification of risks \\
Dry and wet spell frequencies and shifting sensitive crop stages to avoid impacts \\
Changes and trends in rainfall pattern and suitability of new crops and varieties \\
Planning of livestock stocking rate and grazing land management \\
Planning of livestock shelter to reduce impacts of temperature extremes \\
Weather-index-based crop insurance \\
Localised early warning systems for emergency response and humanitarian actions \\
Wind speed and direction & Designing wind breaks and shelter belts \\
& Protect crops from wind-affected lodging \\
& Decide on pesticide and fungicide application \\
Leaf wetness and relative humidity & Disease monitoring, forecasting and management \\
\hline
\end{tabular}

models require weather and soil data along with cropspecific eco-physiological parameters. The reliability of this approach depends on how well we understand the physical and physiological processes involved in the growth of a crop in relation to climate. In addition, there are simple models that convert raw climate data into value-added variables, such as crop water stress/ excess and the water available for crops in the root zone during the growing season; these models are also used for climate change impact assessment (FAO 2010b).

The general procedures for building climate change data towards assessment of agriculture impacts, such as synthetic (incremental), analogous and model-based climate change scenarios, need to be available for agriculture professionals and service providers. National hydrometeorological services participate in strengthening the meteorological monitoring infrastructure, building a climate database, advocating policies at national and regional levels, capacity building, education and training, and often also seek to develop innovative, user-friendly tools and methods to support decision-makers (WMO 2010a).

The FAO has developed climate databases, tools and methods to help reduce the impacts of climate variability and change. Such resources include AgroMetShell for crop monitoring and yield forecasting; CROPWAT for developing options related to the timing and amount of irrigation water to be given to a specific crop; AQUACROP, an FAO crop model to simulate yield responses to water, estimate the irrigation-water requirement and predict yield under different climate change scenarios and irrigation-water management regimes. The databases include FAOCLIM2, agroclimatic data for analysis and interpretation; AQUASTAT, for water and agriculture data and information; and CLIMWAT, a climate database to use with CROPWAT for calculation of the water requirement and to schedule irrigation. Additional details on tools and methods for climate risk management and impact assessment are available at: www.fao.org/nr/climpag/.

\section{INSTITUTIONAL PARTNERSHIPS, NETWORKING, RESEARCH- AND CAPACITY BUILDING}

The capacity to identify, collect and share data, use information and relevant methods for data analyses and build knowledge relevant for climate and weather information and food security is critical. A transfer of recent knowledge from climate science, as well as the strengthening of the capacity for agro-meteorological observation, the development of customised forecasting products, the management of data and the modelling for climate impact assessment and application of climate information at the farm level are of the highest priority. Agriculture extension services need to be strengthened in order to address climate risks and plan for adaptation and mitigation if these are to provide an efficient interface between policy-makers and the farming community. Adapting to climate change and increased climate variability require strengthening of technical capacities of agrometeorological and agriculture extension services in interpreting climate information, preparing impact outlooks and developing adaptation options. 


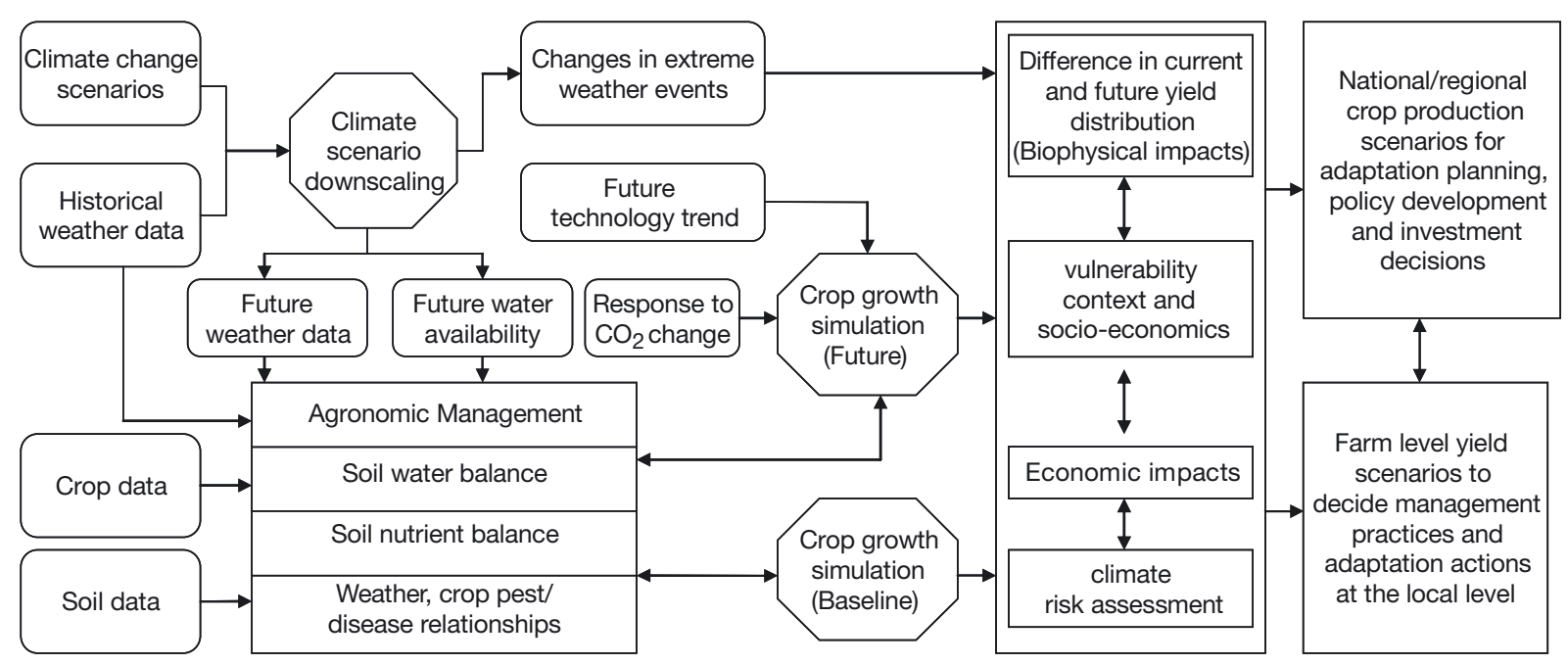

Fig. 6. Data and information flow in a generic climate change impact assessment framework

Agricultural research together with climate science need to provide several new location-specific adaptation and mitigation options. However, research for rapidly changing climatic conditions is different from research for managing past and current climate risks. New investments in research and development and their linkages are required. The priority areas of research relevant to climate science are: improving automated data collection, dissemination and analysis; developing needs-based early warning and forecasting systems; and developing communication protocols and dissemination channels. Significant public and private investments in research and development are required if agriculture is to benefit from the use of new technologies and techniques (FAO 2009a). Meinke et al. (2006) concluded that effective use of weather and climate information requires participatory and practical learning and action research through institutional partnerships and networking. Participatory Action Research (PAR) is the way groups of people can organise the conditions under which they can learn from their own experiences and make this experience accessible to others (Wadsworth 1998). The PAR approach can be adopted for effective application of climate information in agricultural decision making by involving climate services, agriculture support services and users in actively examining together current climate risks and actions in order to improve climate-risk and opportunity management based on the local context. The WMO's (2010b) global framework for climate services was designed to strengthen production, availability and delivery and application of science-based climate prediction and services, and to integrate all necessary requirements for strengthening institutional partnerships, net-working, research and capacity building.

\section{ENABLING POLICY ENVIRONMENTS AND INSTITUTIONALISATION}

The potential to improve farmers' decision-making, leading to increases in farm profits and better informed risk management, through advance information about weather, climate and value-added secondary indices has been well documented (Sivakumar \& Hansen 2007 , Meza et al. 2008, Skees 2008, Mushtaq et al. 2009). These weather and climate information provisions need to be continued, improved and properly institutionalised to ensure sustained operation and institutional support. There are several challenges to be addressed for continued provision of climate information for decision making at national and local levels. The key challenges are financial constraints, changing institutional mandates and disabling institutional policies (Subbiah \& Selvaraju 2007). Maria et al. (2002) recognised the gap that exists between research, policy and users in the generation and use of climate forecasts and emphasised the need to fill these gaps and ensure institutionalisation.

An effective information flow system from information providers to agriculture support services and farmers is feasible within the existing institutional systems in several developing countries. In order to enhance the effectiveness of weather and climate application within the existing institutional systems, developing innovative communication and feedback mechanisms is essential. Such communication and feedback mechanisms can be sustained by the setting up of multi-disciplinary institutional mechanisms at national and sub-national levels with specific roles and responsibilities pertaining to generation, translation, communication and use of climate information for decision making in agriculture. Further, to ensure sus- 
tainability, the government agencies and local institutions seeking the climate information for management of natural resources and climate-related risks and the planning of resilient adaptation strategies can be advised to prioritize the need for climate services in their development plans. Such a prioritization can provide opportunities to leverage funds and technical support for continuous availability of climate information at different levels for pro-active decision making in agriculture and food security.

Enabling local institutions and services, including input suppliers, agricultural cooperatives, regulated markets, etc., need to take an active role in influencing decisions by promoting needs-based advice and new technologies. These enabling institutions need to be autonomous, self-reliant and democratic to advance the continued use of weather and climate services towards sustainable agriculture and food security. Better coordination between formal and informal institutions and active support from climate science would ensure the necessary steps for institutionalisation and would enhance effectiveness through the timely use of weather and climate information by vulnerable communities.

\section{CONCLUSIONS}

Sustainable agriculture is about cautious and optimal use of the natural resource base on which agriculture depends. Understanding the interactions between crops, trees, farm animals and natural resources, such as climate, land, soil and water, is the first step to evolving strategies to contribute to sustainable agriculture. Viewing climate as a resource, climate science can support the characterisation of agroclimatic resources and the identification of suitable agriculture systems that are environment friendly, technically appropriate, economically viable and socially acceptable. The means of support from climate science should include optimising location-specific practices considering natural resources and the current and future climate; enterprise and livelihood diversification depending on climate suitability; and water resource management and water productivity. In addition, integrated watershed management and land use and land-use planning that are dependent on climatic conditions, contribute to the sustainable use of natural resources for agriculture and require specific inputs from climate science.

Sustainable agriculture brings forward the concept of long-term conservation and production. This is a significant shift from the resource mining and production maximisation priorities set during and after the green-revolution of $1960 \mathrm{~s}$. The development of sustainable food production strategies requires a more complete understanding of the limitations and production potentials of crops, livestock, forests and fisheries. Such understanding and characterisation should take into account the emerging challenges due to climate change, growing energy needs and socio-economic scenarios. Support from climate science is necessary to plan for the adaptation of agriculture to temperature changes, changing rainfall variability and patterns, as well as pest and disease outbreaks.

Climate change threatens food systems everywhere, but especially in coastal, mountainous, arid and semi-arid regions, as they are increasingly vulnerable and prone to weather- and climate-related events like drought, dry and wet spells, water scarcity, cyclonic storms, floods, land slides, erosion, seasonal flooding and salinisation. These extremes are not completely new, but their associated impacts on agriculture systems are becoming more intense, because food systems are increasingly infringing on marginal areas less suitable for production. This warrants an integrated climate risk management approach that advocates the use of weather and climate information to optimise resource use and manage risks and to move toward long-term resilient adaptation to climate change. The role of climate science in such a risk management framework is widely recognised, and the potential economic value has been demonstrated. However, a renewed focus on cooperation, collaboration and policy support is necessary to achieve the following goals: to institutionalise efforts related to early warning systems for extreme events; for the application of weather and climate information products; for the promotion of weathercrop insurance; for crop/livestock pest and disease monitoring; and for crop yield forecasting and food security information. All these efforts can contribute to the goal of optimal resource use and the promotion of sustainable agriculture practices for achieving food security.

In the context of climate change, the business-asusual approach may not be sufficient to take care of emerging climate-related risks, especially altered frequencies, intensities and spatial and temporal shifts. Systematic identification of areas of concern with respect to changing biophysical and socio-economic drivers and the planning of location-specific adaptation and mitigation practices are necessary. Customised tools and methods for application of weather and climate information and for vulnerability reduction, climate risk management and adaptation planning in agriculture exist and are continuously being developed. All these efforts need to explicitly seek support in the area of climate science. 


\section{LITERATURE CITED}

Allison EH, Perry AL, Badjeck MC, Adger WN and others (2009) Vulnerability of national economies to the impacts of climate change on fisheries. Fish Fish 10:173-196

Bates BC, Kundzewicz ZW, Wu S, Palutikof JP (eds) (2008) Climate change and water. Technical Paper of the Intergovernmental Panel on Climate Change, IPCC Secretariat, Geneva

Battisti DS, Naylor RL (2009) Historical warnings of future food security with unprecedented seasonal heat. Science 323:240-244

Blanco-Canqui H, Lal R (2008) No-tillage and soil-profile carbon sequestration: an on-farm assessment. Soil Sci Soc Am J 72:693-701

Bond N, Vecchi G (2003) The influence of the Madden-Julian Oscillation on precipitation in Washington and Oregon. Weather Forecast 18:600-613

Challinor A (2009) Towards the development of adaptation options using climate and crop yield forecasting at seasonal to multi-decadal timescales. Environ Sci Policy 12: 453-465

Chavula A, Gommes R (2006) Development of a weather yield index (WYX) for maize crop insurance in Malawi. Food and Agriculture Organization of the United Nations, Rome

De Groeve T, Riva P (2009) Global real-time detection of major floods using passive microwave remote sensing. In: Proc 33rd Int Sym on remote sens environ, May 2009, Stresa, Italy. International Center for Remote Sensing of Environment, Tucson, AZ, p 587-590

Dennis IA, Macklin MG, Coulthard TJ, Brewer PA (2003) The impact of the October-November 2000 floods on contaminant metal dispersal on the River Swale catchments, North Yorkshire. Hydrol Process 17:1641-1657

Donald A, Meinke H, Power B, Wheeler M, Ribbe J (2004) Forecasting with the Madden-Julian Oscillation and the applications for risk management, new directions for a diverse planet. In: Fischer T, Turner N, Angus J, McIntyre L, Robertson M, Borrell A, Lloyd D (eds) Proc 4th Int Crop Sci Congr. The Regional Institute, Gosford, Australia. www.cropscience.org.au/icsc2004/

Doraiswamy PC, Pasteris PA, Jones KC, Motha RP, Nejedlik P (2000) Techniques for methods of collection, database management and distribution of agrometeorological data. Agric For Meteorol 103:83-97

Dovers SR, Handmer JW (1993) Contradictions in sustainability. Environ Conserv 20:217-222

$>$ Dutta SC, Ritchie JW, Freebairn DM, Abawi GY (2006) Rainfall and streamflow response to El Niño Southern Oscillation: a case study in a semiarid catchment, Australia. Hydrol Sci J 51(Issue 6):1006-1020

Easterling WE, Aggarwal PK, Batima P, Brander KM and others (2007) Food, fiber and forest products. In: Parry ML, Canziani OF, Palutikof JP, van der Linden PJ, Hanson CE (eds) Climate change 2007: impacts, adaptation and vulnerability. Contribution of Working Group II to the 4th Assessment Report of the Intergovernmental Panel on Climate Change. Cambridge University Press, Cambridge, p 273-313

FAO (Food and Agriculture Organization) (1995) Dimensions of need: an atlas of food and agriculture. UNFAO, Rome. www.fao.org/docrep/U8480E/U8480E00.htm

FAO (2005) Insurance of crops in developing countries. FAO Agricultural Services Bulletin 159, FAO of the United Nations, Rome

FAO (2007) The state of food and agriculture-paying farmers for environmental services. FAO of the United Nations,
Rome

FAO (2008a) Climate change adaptation and mitigation: challenges and opportunities for food security. Information document prepared for the high level conference on World Food Security: the Challenges of Climate Change and Bioenergy, 3-5 June 2008, UNFAO, Rome

FAO (2008b) Climate change and food security: a framework document. Interdepartmental working group on climate change, FAO of the United Nations, Rome

FAO (2008c) Report of the FAO expert meeting on climate change and biodiversity for food and agriculture. FAO of the United Nations, Rome

FAO (2008d) The state of food insecurity in the world 2008. High food prices and food security threats and opportunities. FAO of the United Nations, Rome

FAO (2009a) How to feed the world in 2050. FAO of the United Nations, Rome

FAO (2009b) Background note on 'More people than ever are victims of hunger'. FAO of the United Nations, Rome

FAO (2009c) Sustainable management of mountains. International mountain day-information note on disaster risk management in mountains. FAO of the United Nations, Rome

FAO (2010a) FAOSTAT, FAO statistical databases. FAO of the United Nations, Rome. Available at: http://faostat.fao.org/ default.aspx

FAO (2010b) Impact of climate change on agricultural yields in Morocco. FAO of the United Nations, Rome. Available at: ftp://ext-ftp.fao.org/SD/Reserved/Agromet/WB_FAO_ morocco_CC_yield_impact/report/WB_Morocco_20091013. pdf

FAO (2010c) "Climate-Smart" agriculture: policies, practices and financing for food security, adaptation and mitigation. UNFAO, Rome. www.fao.org/docrep/013/i1881e/i1881e00. htm

Garrett KA, Dendy SP, Frank EE, Rouse MN, Travers SE (2006) Climate change effects on plant diseases: genomes to ecosystems. Annu Rev Phytopathol 44:489-509

Glantz MH, Gommes R, Selvaraju R (2009) Coping with a changing climate: considerations for adaptation and mitigation in agriculture. Food and Agriculture Organization of the United Nations, Rome

Goddard L, Mason SJ, Zebiak SE, Repelewski CF, Basher R, Cane MA (2001) Current approaches to seasonal to interannual climate predictions. Int J Climatol 21:1111-1152

Gommes R (1998) Agrometeorological crop yield forecasting methods. Food and Agriculture Organization of the United Nations, Rome

Haile M (2005) Weather patterns, food security and humanitarian response in sub-Saharan Africa. Philos Trans R Soc Lond 360:2169-2182

Hall-Spencer JM, Rodolfo-Metalpa R, Martin S (2008) Volcanic carbon dioxide vents show ecosystem effects of ocean acidification. Nature 454:96-99

> Hammer GL, Oosterom EV, McLean G, Chapman SC, Broad I, Harland P, Muchow RC (2010) Adapting APSIM to model the physiology and genetics of complex adaptive traits in field crops. J Exp Bot 61:2185-2202

Hansen JW, Sivakumar MVK, Bates BC (2006) Advances in applying climate prediction to agriculture. Clim Res (Spec Issue) 33:1-2

Hopson T, Webster PJ (2010) A 1-10 day ensemble forecasting scheme for the major river basins of Bangladesh: forecasting severe floods of 2003-2007. J Hydrometeorol 11: 618-641

Howden SM, Soussana JF, Tubiello FN, Chhetri N, Dunlop M, Meinke M (2007) Adapting agriculture to climate change, 
Proc Natl Acad Sci USA 104 (50):19691-19696

Hoyos CD, Webster PJ (2007) The role of intraseasonal variability in the nature of Asian monsoon precipitation. J Clim 20:4402-4424

Ines AVM, Gupta AD, Loof R (2002) Application of GIS and crop growth models in estimating water productivity. Agric Water Manag 54:205-225

IPCC (Intergovernmental Panel on Climate Change) (2007a) Impacts, adaptation and vulnerability. In: Parry ML, Canziani OF, Palutikof JP, van der Linden PJ, Hanson CE (eds) Climate Change 2007: contribution of Working Group II to the 4th assessment report of the Intergovernmental Panel on Climate Change. Cambridge University Press, Cambridge, www.ipcc.ch/publications_and_data/ ar4/wg2/en/contents.html

IPCC (Intergovernmental Panel on Climate Change) (2007b) Mitigation. In: Metz B, Davidson OR, Bosch PR, Dave R, Meyer LA (eds) Climate Change 2007: contribution of Working Group III to the 4th assessment report of the Intergovernmental Panel on Climate Change. Cambridge University Press, Cambridge, www.ipcc.ch/publications_ and_data/ar4/wg3/en/contents.html

Karl TR, Meehl GA, Miller CD, Hassol SJ, Walpe AM, Murray WL (2008) Weather and climate extremes in a changing climate. Synthesis and Assessment Product 3.3. Report by the US Climate Change Science Programme (CCSP) and the subcommittee on global change research, Department of Commerce, NOAA National Climate Data Center, Washington, DC

Kleinen T, Petschel-Held G (2007) Integrated assessment of changes in flooding probabilities due to climate change. Clim Change 81:283-312

Knutson TR, McBride JL, Chan J, Emanuel K and others (2010) Tropical cyclones and climate change. Nat Geosci 3:157-163

Lal R, Follett RF (2009) Soil carbon sequestration and greenhouse effect, 2nd edn. Soil Science Society of America, Madison, WI

Lehodey P, Chai F, Hampton J (2003) Modelling climaterelated variability of tuna populations from a coupled ocean biogeochemical-populations dynamics model. Fish Oceanogr 12:483-494

Lemos MC, Finan TJ, Fox RW, Nelson DR, Tucker J (2002) The use of seasonal climate forecasting in policy making: lessons from northeast Brazil. Clim Change 55:479-507

Luseno WK, Mcpeak JG, Barrett CB, Little PD, Gebru G (2003) Assessing the value of climate forecast information for pastoralists: evidence from southern Ethiopia and northern Kenya. World Dev 31:1477-1494

Meinke H, Nelson R, Kokic P, Stone R, Selvaraju R, Baethgen W (2006) Actionable climate knowledge: from analysis to synthesis. Clim Res 33:101-110

Meza FJ, Hansen JW, Osgood D (2008) Economic value of seasonal climate forecasts for agriculture: review of exante assessments and recommendations for future research. J Appl Meteorol Climatol 47:1269-1286

> Mills E (2005) Insurance in a climate of change. Science 309:1040-1044

Milly PCD, Dunne KA, Vecchia AV (2005) Global pattern of trends in streamflow and water availability in a changing climate. Nature 438:347-350

- Molnar JJ (2010) Climate change and societal response: livelihoods, communities, and the environment. Rural Sociol 75:1-16

Moss RH, Edmonds JA, Hibbard KA, Manning MR and others (2010) The next generation of scenarios for climate change research and assessment. Nature 463:747-756
Muchow RC, Bellamy JA (1991) Climatic risk in crop production: models and management for the semi-arid tropics and subtropics. CAB International, Wallingford

Mushtaq S, Hanjra MA, Chen C, Hafeez M, Maroulisa J, Gabriel H (2009) The economic value of improved agrometeorological information to irrigators amid climate variability. Int J Climatol. doi:10.1002/JOC.2015

National Academy of Sciences (2010) Assessment of intraseasonal to interannual climate prediction and predictability. Committee on assessment of intraseasonal to interannual prediction and predictability, Board on Atmospheric Sciences and Climate, Division of Earth and Life Sciences, National Research Council, The National Academies Press, Washington, DC

Palm CA, van Noordwijk M, Woomer PL, Arevalo L and others (2005) Carbon losses and sequestration following land use change in the humid tropics. In: Palm CA, Vosti SA, Sanchez PA, Ericksen PJ (eds) Slash and burn: the search for alternatives. Columbia University Press, New York, p 41-63

Penning de Vries FWT, Jansen DM, ten Berge HFM, Bakema A (1989) Simulation of ecophysiological processes of growth in several annual crops. Simulation Monograph 29, IRRI, Los Banos, and Pudoc, Wageningen

$>$ Pretty JN, Noble AD, Bossio D, Dixon J, Hine RE, Penning de Vries FWT, Morison JTL (2006) Resource-conserving agriculture increases yields in developing countries. Environ Sci Technol 40:1114-1119

> Romay MC, Malvara RA, Campob L, Alvarezc A, MorenoGonzálezb J, Ordása A, Revillaa P (2010) Climatic and genotypic effects for grain yield in maize under stress conditions. Crop Sci 50:51-58

Rosenzweig C, Iglesias A, Yang XB, Epstein PR, Chivian E (2001) Climate change and extreme weather events. Implications for food production, plant diseases, and pests. Glob Change Hum Health 2:90-104

Selvaraju R, Subbian P, Balasubramanian A, Lal R (1999) Land configuration and soil nutrient management options for sustainable crop production on Alfisols and Vertisols of southern peninsular India. Soil Tillage Res 52:203-216

Selvaraju R, Meinke H, Hansen J (2007) Climate forecast for better water management in agriculture: a case study for southern India. In: Sivakumar MVK, Hansen J (eds) Climate prediction and agriculture: advances and challenges. Springer-Verlag, Heidelberg, p 143-155

Shaw MW (2009) Preparing for changes in plant disease due to climate change. Plant Prot Sci 45:3-10

Sivakumar MVK (2010) Learn to live with less so that others can continue living. Paper presented in the plenary session on adaptation and poverty reduction: Combined forces or a fight against the current? The 3rd deutsche Welle Global Media Forum, 23 June 2010, Bonn. Available at: www.indepthnews.net/news/news.php?key1=2010-06$28 \% 2020: 19: 49 \&$ key2=1

Sivakumar MVK, Hansen J (2007) Climate prediction and agriculture: advances and challenges. Springer-Verlag, Heidelberg

Sivakumar MVK, Gommes R, Baer W (2000) Agrometeorology and sustainable agriculture. Agric For Meteorol 103: $11-26$

Skees JR (2008) Challenges for use of index-based weather insurance in lower income countries. Agricult Finance Rev (spring 2008):197-217

Subbiah AR, Selvaraju R (2007) Institutionalizing climate forecast applications for agriculture. In: Sivakumar MVK, Hansen J (eds) Climate prediction and agriculture: advances and challenges. Springer-Verlag, Heidelberg, p 57-61 
Tadesse T, Haile M, Senay G, Wardlow BD, Knutson CL (2008) The need for integration of drought monitoring tools for proactive food security management in subSaharan Africa. Nat Resour Forum 32:265-279

Thornton PK, van de Steeg J, Notenbaert A, Herrero M (2009) The impacts of climate change on livestock and livestock systems in developing countries: a review of what we know and what we need to know. Agric Syst 101:113-127

Tilman D, Cassman KG, Matson PA, Naylor R, Polasky S (2002) Agriculture sustainability and intensive production practices. Nature 418:671-677

UNDP (United Nations Development Programme) (2006) Human Development Report 2006, beyond scarcity: power, poverty and the global water crisis. UNDP, New York

UNFCCC (United Nations Framework Convention on Climate Change) (2008) Compendium on methods and tools to evaluate impacts of, and vulnerability and adaptation to, climate change. UNFCCC. Available at: http://unfccc.int/ adaptation/nairobi_work_programme/knowledge_resources_ and_publications/items/2674.php

Vega RER (2008) Workbook on climate change impact assessment in agriculture-basic knowledge, methodologies and tools. Caribbean community climate change centre,
Belmopan, Belize

Verdin J, Funk C, Senay G, Choularton R (2005) Climate science and famine early warning. Philos Trans R Soc Lond B Biol Sci 360:2155-2168

Wadsworth Y (1998) What is Participatory Action Research? Action Research International, Paper 2. Institute of Workplace Research, Learning and Development, and Southern Cross University Press, Australia. www.scu.edu.au/ schools/gcm/ar/ari/p-ywadsworth98.html

Webster PJ, Palmer T, Yanai M, Tomas R, Magaña V, Shukla J, Yasunari A (1998) Monsoons: processes, predictability and the prospects for prediction. J Geophys Res 103: 14451-14510

WMO (World Meteorological Organization) (2010a) Building capacity around the world. WMO Bulletin 59, World Meteorological Organization, Geneva, p 46-52. www.wmo.int/ pages/prog/dra/documents/DRA_59_1_en.pdf

WMO (World Meteorological Organization) (2010b) Global framework for climate services (GFCS). World Meteorological Organization, Geneva

WRI (World Resources Institute) (2009) The Bellagio framework of adaptation assessment and prioritization. Working Paper, World Resources Institute, Washington, DC

Proofs received from author(s): February 25, 2011 